\title{
Microbiological Analysis of Critical Points in the Chicken Industry
}

\author{
Rogério Luis Cansian ${ }^{*}$, Salete Teresa Radeski Floriani and Eunice Valduga \\ Departamento Ciências Agrárias; URI-Campus de Erechim; Av. 7 de setembro, 1621; cansian@uricer.edu.br; \\ 99700-000; Erechim - RS - Brazil
}

\begin{abstract}
This work is focused on identifying microbial contamination in the scalding asepsis and cooling processes as well as in fresh sausages obtained. Salmonella was identified in two scald water samples but was absent in the water from chiller and in the final product, which might be explained in terms of chlorine addition and temperature reduction. The analysis revealed that MPN of Escherichia coli was in the range of $<1-11 / \mathrm{mL}$ in the scald water and $<1-64 / \mathrm{mL}$ in the chiller. Aeromonas sp. count showed 5 to $3.5 \times 10^{1} \mathrm{CFU} / \mathrm{mL}$ in the scald water and 9 to $3.7 \times 10^{2} \mathrm{CFU} / \mathrm{mL}$ in the chiller, probably due to the psycrophile characteristics of Aeromonas and evisceration process. The analysis of fresh sausages chicken revealed a sharp increase in the Aeromonas count (2.5x10 $\mathrm{CFU} / \mathrm{g})$. Results showed the need of including Aeromonas analyzes in microbiological tests of foods.
\end{abstract}

Keywords: Aeromonas, bacteria, chicken, microbiology, food quality control

\section{INTRODUCTION}

According to the Brazilian Union of Aviculture, the production of chicken in 1998 was around $4.5 \times 10^{6}$ ton, out of which $3.88 \times 10^{6}$ ton was used in internal market with a per capita consumption of $24 \mathrm{Kg}$. The chicken industry presents a potential to increase the production in about 5 to $7 \%$. In order to achieve this goal the Brazilian Industry should increase the amount exported to other market like Europe. Due to requirements of external market, it is necessary to improve the inspection, microbiologic control areas and hygiene (Puperi, 1999).

It is well known that most food poisoning is caused by the presence of Staphylococcus aureus, Clostridium perfringens or Salmonella $s p$. However, 56 to $70 \%$ of the suspected or accepted cases are classified as unknown etiology. From the 70's, several research papers have shown that gastroenteritis, peritonitis and endocarditis were due to Aeromonas hydrophila and A. sobria (Janda and Duffey, 1988). As public health regulations are becoming continuously strict and punishment increasingly severely, it seems logical and useful to investigate the conditions of food processing concerning contamination.

The most common microorganisms in chicken meat are mesophile and psycrophile bacteria of the animal and of the environment, which are mainly introduced during processing. In general, $A$. hydrophila is considered as an aquatic species, which spreads with the irrigation, laundering, feeding, etc.

Nishikawa and Kishi (1988) found a high number of Aeromonas in different food and concluded that the infections caused by this bacterium were mainly related to the contaminated food ingestion

\footnotetext{
* Author for correspondence
} 
and not from water. Involved food in some cases of affection for Aeromonas have disclosed to levels of contamination of the order of $10^{4}$ the $10^{6}$ CFU/g (Tood, Hardy, Stringer, and Bartholomew, 1991). Fricker and Tompsett (1989) observed Aeromonas in $79 \%$ of different foods.

In fact, there is a lack of information about the occurrence of Aeromonas in food in Brazil, as well as the occurrence of other microorganisms in scalding and chilling water, as coliforms and Salmonella, which are responsible for at least $13 \%$ of the gastroenteritis. The aim of this work was identify microbial contamination due to Aeromonas, Escherichia coli, and Salmonella sp. in the scalding asepsis and cooling processes as well as in fresh sausages obtained.

\section{MATERIALS AND METHODS}

Samples of the scalding and chilling water were collected in the chicken industry on seven different dates. Three samples of chicken sausage from the lots that had contact with the water under investigation were also collected. The analyses of Aeromonas was conducted by counting in Starchampicilin Agar medium (Palumbo, Morgan, and Buchanan, 1985). The sample were serially diluted $\left(10^{-1}\right.$ to $\left.10^{-5}\right)$, according to standard methods of microbiological food analysis (Silva, Junqueira, and Silveira, 1997). All analyses were carried out in triplicates.

The determination of the Most Probable Number (MPN) of fecal coliforms were performed in three series of three pipes, with dilutions of $10^{0}, 10^{-1}$ and $10^{-2}$, using lauril broth sulphate triptosis (LST), shining green broth (incubated at $32^{\circ} \mathrm{C}$ ) and $\mathrm{EC}$ broth (incubated at $44.5^{\circ} \mathrm{C}$ ), for $48 \mathrm{~h}$.

To perform Salmonella analysis, first a preenrichment in lactosis broth was carried out at $35^{\circ} \mathrm{C}$ for $24 \mathrm{~h}$. Selective enrichment media tetrathionate broth (TT) and selenite-cystine broth (SC) were incubated at $35^{\circ} \mathrm{C}$ for $24 \mathrm{~h}$. Then a loopful from each selective enrichment broth culture was streaked in plate with Rambach Agar (Merck) at $35^{\circ} \mathrm{C}$ for $24 \mathrm{~h}$.

The measurements of temperature and $\mathrm{pH}$ in the scalding and chiller water were carried out for each sample.

\section{RESULTS AND DISCUSSION}

The presence of Salmonella sp. was detected in two samples of the scalding water, but not in chilling water and final product. This could probably be due to the reduction of temperature of the water and addition of $5 \%$ of chlorine in chiller, eliminating possible existing contaminations of this bacterium.

The Most Probably Number of fecal coliforms (MPN/mL) varied in the range of $<1$ to 11 in the scalding water and from $<1$ to 46 in the water of chiller (see Fig. 1), which were acceptable values, but showing a clear enhancement in the chiller, mainly due to evisceration step that occur before the cooling (Roitmann, 1988). Temperature of the scalding water varied from 59 to $62^{\circ} \mathrm{C}$, which wont be inhibitory for the majority of the microorganisms, however without capacity of total elimination due to the high microbial load.

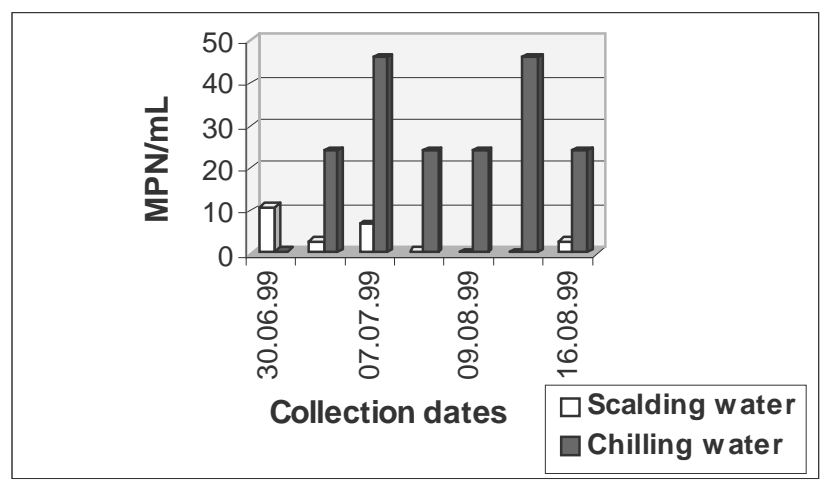

Figure 1 - Fecal coliforms (MPN/ml) in the scald and chilling water analyzed in different dates of collection. 
Fig. 2 presents the results obtained in the analyses of Aeromonas sp. It was observed that count of Aeromonas sp. varied from 0 to $3.5 \times 10^{1} \mathrm{CFU} / \mathrm{mL}$
$(1.54 \log \mathrm{CFU} / \mathrm{mL})$ in the scald water and 9 at $4.0 \times 10^{1} \mathrm{CFU} / \mathrm{mL}(0.95$ at $1.6 \log \mathrm{CFU} / \mathrm{mL})$ in the water of chiller.

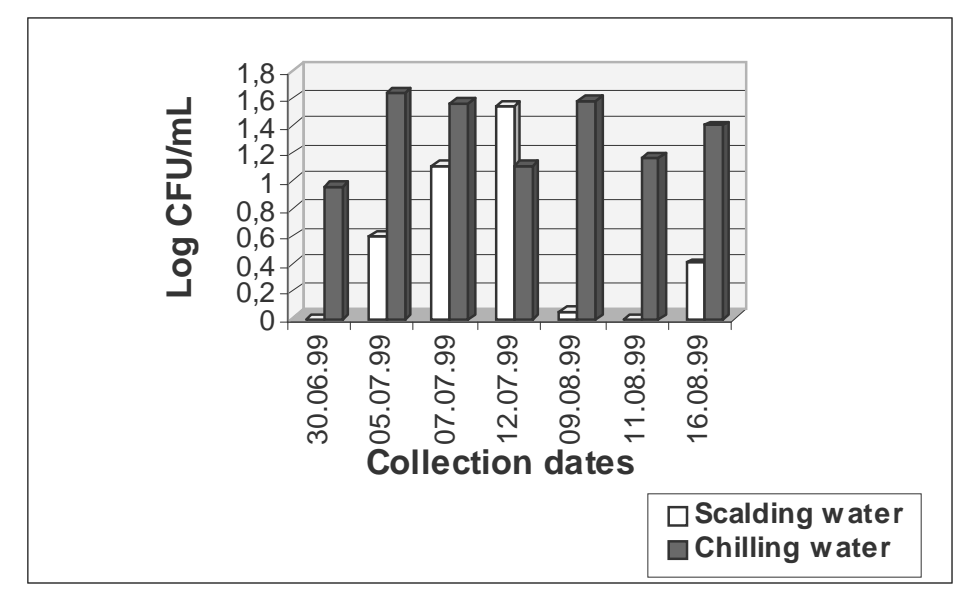

Figure 2 - Aeromonas $(\log \mathrm{CFU} / \mathrm{ml})$ in the scalding and chilling water analyzed in different dates of collection.

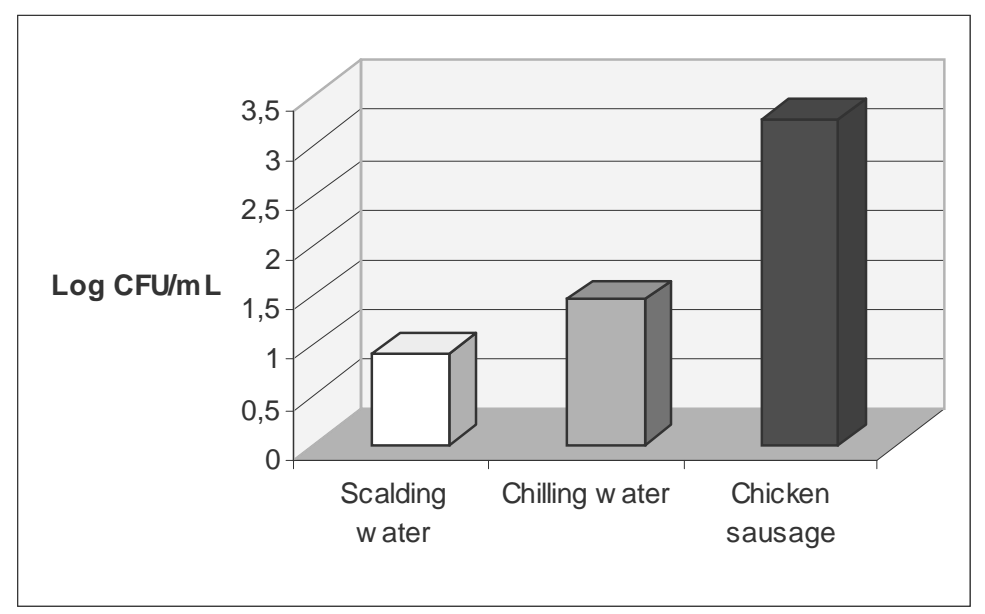

Figure 3 - Average of the growth of Aeromonas (log CFU/ml) in the scalding water, to chilling water and chicken sausage.

This reflected the crossed contamination occurred in the evisceration process before the cooling, an also the fact that Aeromonas be a bacteria psycrophile. Thus, the evisceration process must be carefully accomplished for the control of this bacterium. A possible alteration of $\mathrm{pH}$ of the chilling water could be used as control form, since some reports (Knochell, 1990) indicated the inhibition of Aeromonas at $5^{\circ} \mathrm{C}$ and $\mathrm{pH}$ of 5.3 with addition of salt.

Barnhart et al. (1989) showed more contamination in the evisceration process, which the bacterial counts increasing from $28 \mathrm{CFU} / \mathrm{mL}$ in laundering fluids of death animal to $580 \mathrm{CFU} / \mathrm{mL}$ in laundering fluids after the evisceration process.

The analyses of the chicken sausages showed absence of Salmonella sp. and fecal coliforms with counts up to $110 \mathrm{MPN} / \mathrm{g}$, which was satisfactory conditions for the human consumption (Resolution $\mathrm{n}^{\mathrm{o}} 12$ of 2 of January of 2001, of the Agência Nacional de Vigilância Sanitária, ANVISA).

Fig. 3 presents the counts of Aeromonas. When compared with the average counts of Aeromonas in the scalding and chilling water, an increase was observed in sausage, where the count was up to $1.9 \times 10^{3} \mathrm{CFU} / \mathrm{g}(3.27 \log \mathrm{CFU} / \mathrm{g})$. 
Fricker and Tompsett (1989) demonstrated that in a total of 563 samples of sausages, half of the samples presented Aeromonas sp. Amongst the samples, the meats of chicken (79.3\%) and visceras: kidneys and liver (84.3\%) presented highest incidence of this bacteria. The high frequency of Aeromonas in foods is due to its capacity of growth at low temperature (less than $4{ }^{\circ} \mathrm{C}$ ), which makes it to grow under normal conditions of storage of meats, fish, milky vegetables, products, etc (Knochel, 1990; Krovacek, Faris and Mansson, 1991; Beuchat, 1991).

The high temperature of the scald water and low chilling temperature associated with the chlorine use are sufficient for the control of fecal coliforms and Salmonella levels. However, there were probably the cross infections and psycrophile characteristic of Aeromonas hydrophila, which remained viable after the treatments and presented growth in fresh sausages conserved under refrigeration temperature. This fact demonstrated the necessity to include Aeromonas hydrophila in the microbiological food evaluations. Currently Holland and Canada demand its determination in drinking waters and are considered test recommended in the United States and some countries of the Europe, as much for waters as for foods.

\section{RESUMO}

O objetivo deste trabalho foi identificar a contaminação microbiana no processo de escaldagem, assepsia e resfriamento do frango (chiller), e em linguiças de frango produzidas a partir destes. As amostras foram coletadas em um frigorífico de aves, em sete datas e analisadas em triplicata. A presença de Salmonella foi detectada em duas amostras da água de escaldagem não estando mais presente na água do chiller e nem no produto final. Isto se deve à redução de temperatura da água e adição de cloro. O NMP de coliformes fecais variou entre $<1$ a $11 / \mathrm{ml}$ na água de escaldagem e $<1$ a $64 / \mathrm{ml}$ na água do chiller, que embora em padrões aceitáveis, mostram tendência de acréscimo no chiller, devido principalmente ao processo de evisceração. As contagens de Aeromonas variaram de 5 a $3,5 \times 10^{1} \mathrm{UFC} / \mathrm{ml}$ na água de escaldagem e 9 a $3,7 \times 10^{2} \mathrm{UFC} / \mathrm{ml}$ na água do chiller. Este acréscimo se deve, provavelmente, por Aeromonas ser psicrófila e também devido a retirada das víceras. As análises de linguiça de frango mostraram acréscimo nas contagens de Aeromonas, apresentando até $2,5 \times 10^{3} \mathrm{UFC} / \mathrm{g}$. Esta tendência de aumento de crescimento no produto final, aliado a capacidade de causar infecções de Aeromonas demonstram a necessidade de incluir a análise destas nas avaliações microbiológicas de alimentos.

\section{REFERENCES}

Barnhart, H. M.; Pancorbo, O. C.; Reesen, D. W.; Shotts Jr., F. B. (1989), Recovery of Aeromonas hydrophila from carcasses and processing water in a broiler processing operation. Journal Food Protection, 52, 646-649.

Beuchat, L. R. (1991), Behavior of Aeromonas species at refrigeration temperatures. Int. J. Food Microbiol., 13, 217-224.

Fricker, C. R. and Tompsett, S. (1989), Aeromonas spp in foods: a significant cause of food poisoning. Int. J. Food Microbiol., 9, 17-23.

Janda, J. M. and Duffey, P. S. (1988), Mesophilie aeromonas in human disease: current taxonomy laboratory identification and infectious disease spectrum. Rev. Infec. Dis., 10, 980-997.

Knochel, S. (1990), Growth characteristics of motile Aeromonas sp. Isolated from different environments. Int. J. Food Microbiol., 10, 235-244.

Krovacek, K.; Faris, A. and Mansson, I. (1991), Growth of and toxin production by Aeromonas hydrophila and Aeromonas sobria at low temperatures. Int. J. Food Microbiol., 13, 165-176.

Nishikawa, Y. and Kishi, T. (1990), Isolation and characterization of motile Aeromonas from human, food and enviromental specimens. Epidemiol. Infect., 101, 213-223.

Palumbo, S. A.; Morgan, D. R. and Buchanan, R. L. (1985), Influence of temperature, $\mathrm{NaCl}$, and $\mathrm{pH}$ on the growth of Aeromonas hydrophila. J. Food Sci., 50, 1417-1421.

Puperi, C. (1999). Exportação em 1999. Jornal Correio Riograndense. Pág. 717 março de 1999.

Roitman, I. (1988), Tratado de Microbiologia. São Paulo : Manole. Cap. 1. 176 pp.

Silva, N.; Junqueira, V. C. A. and Silveira, N. F. A. (1997), Manual de métodos de análise microbiológica de alimentos. São Paulo : Livraria Varela. 295 pp.

Tood, L. S.; Hardy, J. C.; Stringer, M. F. and Bartholomew, B. A. (1989), Toxin production by strains of Aeromonas hydrophila grown in laboratory media and prawn purée. Int. J. Food Microbiol., 9, 145-156.

Received: April 26, 2004; Revised: September 03, 2004; Accepted: March 01, 2005. 